\title{
HISTORICAL TALES (IBITEEKEREZO) AND THE HISTORY OF RWANDA
}

\author{
JAN VANSINA \\ UNIVERSITY OF WISCONSIN-MADISON
}

Historical tales are the most abundant and the sources most used to reconstruct the history of the kingdoms of the area between the Great Lakes. This is cspecially true for the history of the Nyiginya kingdom in Rwanda, where such tales, preserved at the court as well as by local people on the hills, are even more abundant than anywhere else.' It is not surprising then that they form the bedrock on which authors have built their reconstructions on the history of that kingdom. ${ }^{2}$ Yet little attention has been paid to a general critical examination of these tales. ${ }^{3}$ Here, and elsewhere in the region, their contents have generally been accepted as credible, after the arbitrary erasure of all references to passages judged to refer to miracles, after the arbitrary dismissal of the bits and the variants that do not conform to one's preferred version, and after either the exclusion of local "provincial" narratives, or as happened after 1960, the exclusion of all those that stemmed from the court. Such practices will simply not do.

\footnotetext{
'To distinguish between the territory of the present Republic of Rwanda and the area corresponding to the former kingdom of central Rwanda, we will call the latter the Nyiginiya kingdom after the clan name of its rulers. The spelling of Kinyarwanda adopted, except for our omission of tones, follows the usage in A. Coupez and Th. Kamanzi, Récits historiques rtuanda dans la version de Gakaniisha, Tervuren 1962:14 (general), 15 (vowel-length notation).

'The most significant reconstructions are A. Pagès, Un royaume bamite au centre de I'Afrique (Brussels, 1933); P. Schumacher, Ruanda (Microbibliotheca Anthropos, 28a) (St. Augustin,1958); A. Kaganne, Inganii Karinga (2 vols.: Kabgayi 1943-47; 2d. ed., 19.59); A. Kagame, Un Abrégé de l'ethno-histoire du Rwanda (Butare, 1972) and A. Kagane, Un Abrégé de I'histoire du Rivanda de 1853 à 1972. Tomie deuxième (Butare, 1975). Although Kagame, Alrégé I:9-17, denies that ibitcekerezo form the foundation of his work, it is in fact mostly based on these sources, including the "mini tales" provided by esoteric coinmentaries on the rituals of kingship.

'J. Vansina's short essay Evolution du royaume du Rıvanda des origines à 1900 (Brusscls, 1962), 20-24, presented these sources only in a general way.
}

History in Africa 27 (2000), 375-414. 
Because these tales form the bedrock of the history of the kingdom the Institute for Scientific Research in Central Africa (IRSAC) under my direction instituted a large collection of such sources between 1958 and 1962, and made them available in the original and in translation first in depots at Butare and Tervuren and later in 1973 on microfilm. ${ }^{4}$ Surprisingly enough, this collection as well as even major editions of other sources, have been completely ignored by most

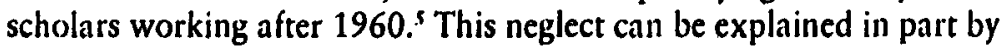
the revolution which occurred in Rwanda between 1959 and 1962, and which included among others the abolition of the Nyiginya monarchy and a rejection of Tutsi rule. Most scholars from then on have dealt with "the periphery" of the old kingdom, that is those areas around it which came mostly under its sway in the nineteenth century or even later.

Moreover most of these scholars, as was then the practice in anthropology and sociology especially, based their results only on oral data they had collected themselves, as if it would be improper to use data collected by others. They did not realize that they should have used these data in the same way that historians use archival material. As a result of their a priori dismissal of sources from court circles, the ignorance of some scholars about the IRSAC collection sometimes astonishes. Thus Vidal, and Nyagahene in her wake, accused me of drawing the substance of my data from Kagame's publications as an "informant." They did not realize that nearly all these stemmed from the IRSAC collection and that Kagame was only cited as one cires other historians, who use parallel source material or sources inaccessible to others. ${ }^{6}$ Indeed the resistance of scholars to making use of the IRSAC collection reached amazing heights. Thus Nkurikiyimfura based his whole dissertation on ibiteekerezo he claims to have recorded from Jean Mugina, a person who had already contributed some forty hours of recording to the IRSAC collection.' If so, he should obviously have compared his recordings with those of Mugina

4]. Vansina ed. Ibitéekerezo: Historical Narratives from Rıvanda (Chicingo: CIRL/CAMP (CRL), 1973) about 6000 pages.

'Especially Coupez/Kamanzi, Récits; M. d'Hertefelt and A. Coupcz, La royauté sacréc de l'ancien Rivanda: texte, traduction et commentaire de son rituel (Tervuren, 1964 ), and P. Smith, Le récit populaire an Revanda (P'aris, 1975). Orher contributions pulblished before 1980/87 can be found in M. d'Hertefelt and D. de l.anc's cncyclopedic bibliography, Societé, culture et histoirc du Ruanda (2 vols.: Tervuren 1987).

"E.g., C. Vidar, Sociologie des passioms (Paris, 1993), 56-59, A. Nyalgihene, Histoire et penplememt: ethnics, dans, lignages dans le Ruanda ancien et comtemporain (Paris, 1997), 34, 37-38.

J-N. Nkurikiyimfuril, "La révision d'unc chronologic : le cass du royanume du Rivanda"


\$2.3. 
in the IRSAC collection, unless of course he actually used the IRSAC data, yet claimed them as his own.

Sight unseen then, most scholars apparently dismissed all publications of soutces about the Nyiginya kingdom stemming from milieus at court as spurious. They acted as if they had decided that (a) oral traditions, especially tales stemming from the Nyiginya court, are not credible and are misleading; (b) there was nothing in this IRSAC collection for the local history each of them studied; and (c) Kagame had made full and faithful use of the ibitcekerezo in his history of the Nyiginya kingdom. All three points are wrong. As to (a), one cannot simply dismiss any purported sources out of hand without showing exactly why they do not stand up to the canons of evidence. As to $(c)$, Kagame made a very selective use of tales and gives a heavily edited and slanted interpretation of them, something that becomes truly apparent only when one compares his statements with the relevant publications of sources. As to (b), some local traditions were included in the collection which was not narrowly confined to court circles. Besides that oral tales, even under court influence, still remain sources." Moreover, scholars with this attitude ignored the fact that the Nyiginya kingdom exerted a certain impact on most peripheral regions within and even beyond the present Republic of Rwanda, so that sources from the court cannor simply be ignored, even for local history. Given such attitudes, it is not surprising that the precolonial historiograplyy of the Nyiginya kingdom especially, but even of Rwanda in general, has stagnated."

It is therefore more than high time to draw attention to the large bodies of available sources, especially the historical tales, and to show how to subject them to a critical examination which then allows the historian to make good use of them. Hence our aim is to illustrate how the ignored corpus of tales in the IRSAC collection can be analyzed as a source of history and what it can contribute to the history of the Nyiginya kingdom. This collection contains mostly historical tales (ibiteekerezo), shorter historical communications about more recent times (amakuru), and dynastic poetry, from all over the country, as well as samples of all other genres, barring only the liturgy of the royal rituals (ubwiiru) or secret commentaries relating to this liturgy (inteckerezo), to which we had no access.

Of the over 1000 items in the collection, about 900 are records of ibiteekerezo or amakuru. These represent well over 300 different gen-

"A more intensive search for local traditions was carried out from 1959 onwards and at lenst some local history was recorded in all but two or three of the historical provinces of the country of Rwanda.

"Nyagnhene, Histoire: 680 , spenks of the "the trampling in place which Rwandan historiography exhibits today, especially with regard to the precolonial period," but he did not make use of these sources either, let alone apply the rules of evidence to them. 
eral ibiteekerezo, which were known at the royal court, and at least 100 local tales. Compared even to other Great Lake kingdoms 300 general historical tales is a very high number and shows the importance of history at the court as a fount of legitimacy and a justification for action. By using this collection, as well as the text edition of "bwiiru, researchers have direct access to many of the sources on which the early history of the Nyiginya kingdom has been built. It is unfortunate though that no publication of "raw" inteckerezo exists at all. Alexis Kagame claims that his synthesis is primarily based on these data, but he has never published any of them on the grounds that they were as secret as ubwiiru irself. "Judging, however, by the summaries which he did use in his books these commentaries appear to be short narratives as well.

The first question to ask is what are Ibiteekerezo (sg igiteekerezo)? They are narratives of various length deemed to be historical as opposed to fictional." The term itself means "reflection, thought" and derives from the verb-téekerez-"to think, to ponder" and aims as much to offer one's thoughts to the auditors as to narrate events of the past. ${ }^{12}$ Loosely speaking, the term applies to all historical narratives irrespective of style, origins in social terms (whether from the Nyiginya court or local), or period of contents. It is in this sense that the IRSAC collection carries that label. Strictly speaking, however, ibiteckerezo are rather long and complex, are told in the refined flowery language of the court, stem from that milieu, and deal with carlier times, not with contemporary or subactual happenings. The latter are the stuff of terser narratives about "new information" or amakuru, a term derived from kuru "old" which, in contrast to ibiteekerezo, refers to historical content. ${ }^{13}$ From this point of view, many of the shorter tales of the late eighteenth and nineteenth century which are labeled ibiteekerezo here are in fact amakuru.

Ibiteekerezo were usually performed (even in 1958-60) by a more or less renowned storyteller, often of unremarkable social pedigree, at the house of some great personage and his/her noble friends during an evening of boisterous relaxation. 14 In this setting the art of the performer, usually very much a commoner, consisted in understatement

\footnotetext{
"A. Kagane, "Le code ésotéricjue de la dynasric du Rwanda," Znire 1(1947): 364-6.5, 373; idem., Abrégè: 11.

"Simith, Recit, 15-17, 69-109; Coupez/Kamanzi, Récits, 7-8

"Smith, Récit, 15-16; Coupez/Kannanzi, Récits, 7. Tone is indicated in discussions of etymologies.

"Sinith, Récit, 15-16; Coupez/Kamanzi, Récits, 7-8.

"lagès, Royaume, S50-51. His olservations began in 1908.
} 
or allusion. One strove to tell the tale quietly without much gesticulation, relying for effect mainly on intonation and subtle changes in the voice, and sometimes on dialogue. This sort of presentation was wholly at odds with the performance of various types of poetry by men of substance. Those were accompanied by much leaping and shouting as an indication of the poet's importance.

All ibiteckerezo storytellers were men, expressed a well-to-do man's view of the world, and were professionals or semi-professionals. But, unlike the situation with regard to the official dynastic regnal list, the court had not created an office of Court Historian, nor restricted the memorization of these tales to specific families. ${ }^{15}$ The repertoire of many tellers, such as Gakaniisha or Mugina, included a large number of tales spread over the whole chronological range of the corpus and they strove to increase it by learning new pieces from others. ${ }^{\text {it }}$ It is from the court that even the earliest writings about the history of the Nyiginya kingdom were derived, although courtly tales were not limited to the royal court. ${ }^{17}$ They were also told at local gatherings, usually of chiefs, all over Rwanda, often by people such as Gakaniisha, who had learned them at court and had then settled elsewhere. ${ }^{18}$ At least from the onset of this century, and probably much earlier on, even some ordinary people everywhere knew and recounted ibiteckerezo. Some of these narratives, which exhibit considerable literary sophistication, complexity, and intricacy tended to be favorites of both storytellers and their audience, while shorter anecdotes about miraculous exploits, especially those of the folk hero king Ndoori, became so popular that almost every Rwandan knew at least a few of these. ${ }^{19}$

Yet the term ibitcekerezo has also been applied to local tales told in more homely surroundings and in less exalted language by local people. Indeed sometimes the label has been applied to outright statements about historical rights over land or a list of people's forebears, accounts so terse as to become more like a string of names rather than being what outsiers would call a tale.

The transmission of these tales, even at court, was unregulated. Even though sons often learned from their fathers, any man with a natural talent-that is, a retentive memory and a way with words-

\footnotetext{
"A. Kagame, La notion de génération appliquée à la généalogie dynastique et à I'bistoire du Rwanda des Xe-Xle siècles à nos jours (Brussels, 1959), 32.

"Coupez/Kamauzi, Recits, 7. Gakaniisha presented some twenty tales over ten hours of taping in 19.52/54; in the IRSAC collection Mugina told about forty of them over 20 hours.

'E.g. Pilgès, Royaume, 73-74, 550.

${ }^{1 x}$ Coupez/Kamanzi, Recits, 7, for Ciakaniisha's family links to the court as tanners, a typical background for many storytellers.

"Snith, Récit, 76.
} 
could tell them and derive some personal prestige, as well as rewards from them. There was no provision, even at court, to teach tales formally. Yet it is remarkable how little change in a tale can be discerned in two versions told by the same storyteller even after several years. ${ }^{20}$ Nevertheless, the variants of the same tale by different storytellers do show the effects of the haphazard nature of transmission. They exhibit not just differences in wording, but also the contraction or expansion of particular episodes or the inclusion of new episodes which come often as an introduction to the tale or result from confusion between similar episodes in different tales. Divergent materials are sometimes inspired by a popular saying or even borrowed from another tale. Then there is the use, or not, of dialogue, and, in the cases of some popular complex narratives, even the introduction of new subplots or the fusion of several tales around one leading actor into a single new tale (e.g., Nyanguge). ${ }^{21}$

An examination of variants soon establishes this tendency. One is irresistibly reminded of what occurs in the production of historical movies! Indeed, such dynamics were precisely what made the artistic production of ibiteekerezo so interesting. Given this sort of transmission, "backfeeding" should be expected, not just from oral sources, but also from written sources in Kinyarwanda and even in French.22 In the IRSAC collection an incomplete recitation by Mugina of the dynastic list of kings concludes as follows:

The reason that I cut this royal genealogy is that I only know it up to that point. But what remains behind I can also explain a little bit. As soon as I am better informed about it I will come back to explain the rest. ${ }^{23}$

In sum then, individual ibiteekerezo change somewhat over time as different, more or less comperent storytellers, add their own touches. ${ }^{24}$ At the same time though many of the idiosyncrasies they

\footnotetext{
2"As an experiment, Gakaniisha performed a tale for us in 1958-59 which he had first told in 1952. There was no change in plot, sequence of episodes, actors, or scenery, and even the differences in language were guite minor.

"E.g., the tale of Nyanguge $T$ and $H$. Refcrences to tales in the IRSAC collection are by the names of kings, which are used as file headings, or other file headings, followed by $T($ taped records) and $H$ (recorded by hand), followed by \# and the number of the item in the file. When any number follows that, it refers to the paige of the documest in its French translation.

22Both editions of Kagame's Inganii Karinga were especially accessible, as now is his Abrégé. A spectacular example is the citation by "the greal 'vassils' of the court" in Temps Nouveaux (6 August 1958). There twelve conscrvative politicians use Inganji Karinga as an authority against Hutu rights. Written versions or stummaries in French date from as early as the late 1910s and were known to the elites. The best known of these was Pagès, Royaume bamite.

"Divers, T,\# 35: 4-5.

${ }^{24}$ On incompetence see Sinith, Récit, 19.
} 
introduced died out because others among the many storytellers did not adopt them. What mattered most was the reception by the audience. Any particular rendering that met with great approval at court tended to be imitated. Over time, as aesthetic tastes and political interests changed, so did the appreciation of particular ibiteckerezo and of particular renderings of each of them. Unfortunately, we cannot measure such changes, but only give an impression of a rate of change affecting an individual tale in a substantial way. Such an impression is based on the degree of variance within a tale as to plot, sequence of episodes, scenery, and actors, and to some extent also on its place in the overall corpus. All in all, though, in most cases the rate of change as to substance within each tale seems to have been slow. But changes in repertoire of ibiteekerezo may have occurred more frequently as some tales fell out of favor while others became favorites at court for political or aesthetic reasons.

The main actors or heroes of these tales were usually kings, but they could also be queen mothers or queens, princes, divining prophets both men and women, and even entities such as armies. Sometimes a set of similar tales are told about the same hero, e.g., the magician king Mashira or king Ndoori, and thus form a cycle. But each story remains a separate tale with its own exposition, developinent, and resolution, even in a cycle. This situation entails that even the most complex tale will remain anecdotal. A history of the Nyiginya kingdom based on ibiteekerezo is like a string of anecdotal beads, each bead being strung on an overall common plot provided by the chronology of kings as established in the tradition concerned with the dynastic succession, the ubucuurabwenge. ${ }^{25}$ In addition, since the character of a tale can vary from fairy tale to statement of fact, the stability of the link between the plot and the names of persons or places mentioned, must be established in each case, taking anachronisms into account, e.g., those that refer to localities by the name of present chiefs. For without an assurance that the names of the main actors and places are an essential parts of a given tale, that tale cannot have any value to the historian. A study of variants allows one to establish the quality of this link.

The themes of most historical tales are limited. The ibiteekerezo stemming from the court deal with intrigues at court, political marriages, duels of magic, feats of extraordinary divination, cattle herds, and war-"conquest" being only mentioned incidentally or even inferred as a result of war. Many of the local tales focus on matters of settlement and the history of changing rights over land or cattle. This

\footnotetext{
"For the "bucuurabuvenge only, Schunacher, Ruanda: $122-44$, gives various versions received from named specialists; Kagane, Notion, 14-27; Nkurikiyimfura "Révision," 149-80; and IRSAC "divers" T \#10 by Jean Mugina.
} 
restriction of the repertoire to aspects of the past which are of great interest to people living in the early twentieth century, limits its use in historical reconstruction, even more than their anecdotal character does. But it does not prohibit it. Sometimes tales also include incidental remarks which play no necessary role as image or as object of action in the plot or the episodes, such as mention of the introduction of a new crop. These can be valuable, although in most instances they are anachronisms created by the need to provide a vivid lifelike atmosphere for the tale. For instance, descriptions of the use of tobacco in early times by the main characters are legion because they are a sign of refined living and hence something which important persons would have done. Beyond a general structural analysis of a tale, a study of its variants often allows one to evaluate the stability of such incidental information across the variants. Information which does not occur regularly must be attributed to the artistry of individual narrators.

The whole corpus of these narratives constitutes first and foremost an irreplaceable record about the historical consciousness of Rwandan men in the first half of the twentieth century. It also documents many of their customs, as well as their attitudes and opinions about many cultural and social issues of their time. By their concrete descriptions of settings, the tales show how material culture was integrated in the then current social, intellectual, and emotional life. So far no one yet has used these sources for such a purpose, not even, for example, to document perceptions in the 1950s of the range of then current meanings of the words Hutu and Tuutsi.

\section{III}

With due precautions the ibiteekerezo also constitute an indispensable source for our knowledge about the more remote past. The early written reconstructions of the history of the Nyiginya kingdom were all based on ibiteekerezo arranged in the order of kings as taught by the official keepers of the dynastic succession list. Even the final synthesis of Kagame is still very much indebted to historical narratives, despite his claim that he based his reconstruction on other oral traditions such as poetry, genealogies, the list of dynastic succession, the commentaries on ubwiiru, and the attribution to certain kings of drums, burial places, the creation of armies, or royal herds. Nevertheless, even a superficial look at his reconstruction shows that his overall narrative framework still rests on his interpretation of ibiteckerezo and that most of his other information stems in fact from inteekerezo, i.e., esoteric or secret explanations or commentaries given by the keepers of the royal ritual lore (abiiru). These arc designated in Kinyarwanda by the root-téckerez-, but with a different prefix. ${ }^{26}$

insinith, Recit, 15 
Most of these seem to consist of anecdotal short narratives but some are longer. ${ }^{27}$ Inteekerezo present worse problems of credibility than ibiteekerezo do because their sensitive nature also meant that they would be affected more often by changing political circumstances and because such wilful changes were easy to introduce given the secrecy of the record and the small number of those who kept the oral record. Moreover, one must also consider that the shorter a communication, the smaller the mnemotechnic set of cues in it and the greater the chance for error. Unfortunately, and in contrast to ibiteckerezo, we cannot evaluate these inteckerezo at all, because Kagame kept his original sources of this type, as distinct from his interpretation, totally secret. ${ }^{2 x}$

By itself this last point underscores the absolute necessity to make available collections of records. ${ }^{2 y}$ In addition, the absolute necessity to compare variants of the same tale and to compare tales with each other to establish their reliability also requires a collection of records. The records gathered by IRSAC provide such a collection, to which one should add records published elsewhere and summaries of the individual tales which appear in earlier works."

\section{IV}

Perhaps the best way to present the issues which confront the histotian who uses ibiteekerezo as evidence is to present a concrete case first."

We take for this the only two tales in the IRSAC collection which deal with king Yuhi Gahima. As it happens, these two tales also represent the two different types of historical tales in the collection. The first type is represented by "Yuhi against Samukeende and his wife Nyagakeecuru ," a record written down by hand and hence already quite condensed. We summarize it here: ${ }^{32}$

\footnotetext{
2'E.g., the account of how Rundi diviners imposed the regnal name Mutara is a fullfledget cale C.. Kagame, Alrégé 1:111-13. It clashes with all the ibiteekerezo, which ascribe this more logically to Mpande, the famous court diviner of the time.

2xFor a severe and detailed critigue of Kagane's work, see A. Coupez, "Magie et ictéologie face ì l'histoire du Rwauda," Cultures et Développement 6/1(1974), 13.5-47. "And the importance for the history of Rwanda of Kagame's original papers, should they have survived. They should be deposited in an archive and made accessible to the public.

"E.g., Coupez/Kamanzi, Récits; Smith, Récil; and the summaries in Pagès, Royaume, and Kagame, Abrégé.

"In this essay kings are referred to only by their own ("Tutsi") name, except where the reginal name is of importance to the discussion. For the placement of ench king in chronological order, see the conventional list of rulers in the appendix.

"Gahima $\mathrm{H} 1$.
} 
Yuhi wanted to eliminate a certain kinglet Samukende, master of a small territory near Mubumbano at the place called at "the great rock of Shaari." But this man repeatedly defeated him. Finally his diviners prophesized that Yuhi's wife should have intercourse with Samukende. A boy would be born of this union who would be the heir to Samukende and defeat him. Yuhi's wife dutifully went to visit the kinglet and his wife Nyagakeecuru, who was her sister. But Samukende's diviners warned him not to approach his guest. Still, when Samukende was drunk and while her sister was asleep, Yuhi's wife succeeded in having intercourse with the kinglet and was immediatedly impregnated. Thereupon she fled back to her husband, pursued by the armies of Samukende but was rescued by those of Yuhi. Seeing that he could not catch the woman who was pregnant with his heir, Samukende broke his spear and his bow and drowned himself in a river.

Now Nyagakeecuru could be attacked. But the enclosure around her residence was quite thorny so that access into it was extremely difficult. Moreover, there was a snake which prohibited the armies from approaching it. Yuhi sent a gift of goats to Nyagakeecuru and these soon browsed all the vegetation of the enclosure. Meanwhile Binaama the son of Samukende and Yuhi's wife had grown up to be. come strong and courageous. He spearheaded the attack by the Rwandan army to overrun Nyagakeecuru.

Fatally hit by a spear in battle, he cursed the descent group of Samukende and was then swallowed by the earth, whereupon the famous rock known as "the great rock of Shaari" rose out of the soil., After Binaama's death, the armies of Nyagakeecuru were defeated.

The second story was taped and is entitled "Nyirantebe." 34 A full translation of the original text runs as follows:

Nyirantebe was a king's daughter. She inherited Nyakare [province]. She stayed there and governed this province with her husband and her children until her old age. It was under the rule of Yuhi Gahima. It was at this time that Nyirantebe resided in Nyakare. After her death she was succeeded respectively by her children and her grandsons. After this though, Kanyangamwe, son of [king] Rwogera, obtained this province and governed it. Seesikeeye, son of Ntuuro succeeded him and left the government of it to his son Mutembe. This one was succeded by Gitambaro.

This is all I know about Nyakare [the province]. All of it belonged in fact to Nyirantebe, daughter of the king. She had inherited it from her husband.

This then is what I know concerning Nyirantebe.

The contrast in genre between the two stories is vast. The first is a summary version of one of the typical ibiteckerezo in the narrow

"Probably the hill labeled Shori on the inaps, almost duc south of Butare.

wYuhi Gahima, T\#1; [JVO] 1. 
sense. The second is so only in a very loose sene. It is a matter-of-fact statement about local history, giving us the succession of officeholders in Nyakare. No doubt the second story seems much more credible than the first.

But is it totally reliable? Nyakare is also the name of a regiment, created according to Kagame, by king Ndoori with warriors who had immigrated from Burundi under the command of the elder Bashana. ${ }^{3 .}$ Later, under king Cyirima Rujugira, the Nyakare army, commanded by Nkoko, was established in a permanent camp facing Burundi, in the territory known from then on as Nyakare. ${ }^{36}$ These data seem to conflict with the local information. Looking more closely at the latter, it is evident that Yuhi Gahima cannot be the king "under which this occurred," because the number of generations given in the record excludes it. Nyirantebe's grandchildren lived approximately during Rwogera's reign, as they were succeeded by his son. This means that Nyirantebe received Nyakare less than two generations earlier. Rwogera's predecessor, Yuhi Gahindiro, came to the throne as a baby and hence it is more than likely that the tradition has confuses the two Yuhi and that Yuhi Gahindiro's reign was intended. Nyirantebe herself was the daughter of an earlier king, probably Ndabarasa rather than Sentaabyo, who only ruled for five years and died young. What we have here then is a local tradition which goes back, like many others in the present prefecture of Butare, to Gahindiro only, thereby eliminating earlier events. Further local information about Nyakare may tell us whether the succession list given in it is as reliable as it seems to be.

This first story requires much more commentary. To begin with, let us compare this version with what Kagame made of it. In his version Yuhi Gahima sent his wife, named here, to have a child with Samukende, the king of Bungwe. The wife returned to Rwanda and gave birth to a child named Binaama, as suggested by his legal father Yuhi. The newly-born was to be a liberator against the kingdom of Bungwe. Liberators are people who by being killed by the enemy magically ensure Rwanda's victory. In this case Kagame claims that, according to the esoteric code (i.e. ,the inteekerezo, to which he was privy?), no dynasty can resist if attacked by a warrior, and even better, a liberator of its own bloodline. He then tells us more about Binaama. He was the eponymous ancestor of the Abanaama family. In a later passage, Kagame continues with an episode, which is not in this version, which tells how king Ndoori failed to overcome Nyagakeecuru, without mentioning the fence, the snake, or the mean-

\footnotetext{
"Kagaine, Abrégé I:108. In this context "Burundi" cannot designate the kingdom, only the area where that kingdom later arose.

in Kagaine, Alrégé 1:137-38.
} 
ing of word Nyagakeecuru ("little old woman" i.e., "sorceress"). ${ }^{37}$ In a later passage of his book concerning the reign of Seemugeshi, Kagame conludes with the information that Binanma overcame her, but was killed, without mentioning the miracle of the "great rock of Shaari" at all, although it is crucial in this etiological tale because the rock anchors it to a specific place. ${ }^{3 *}$

The reader may not be aware either that Binaama's death is the very point of the first part of the tale and should therefore not have been separated from it. Nor are we told that in the tale all this occurs in the reign of Yuhi Gahima. In addition, Kagame tells us that, according to "memorialists," i.e., storytellers, a Binaama, who for him is the same person, was one of the supporters of king Ndoori and lived in the northeast of the kingdom at Jali when Ndoori came to power. ${ }^{3 y}$ Thus Kagame draws this out over three generations because Seemugeshi is supposedly the third king, in the third generation, after Gahima! In short, Kagame has sanitized the whole tale, ignored its structure, rearranged its internal time, and added other data concerning the same names in an effort to make it all very realistic, matter of fact, and hence credible.

But this is not all. The IRSAC collection has another version of this tale in the file of Yuhi Mazimpaka told by the master storyteller Jean Mugina. ${ }^{411}$ In this one Binaama, son of this Yuhi, rather than of Yuhi Gahima, deals with Burundi. The first sentences are confused and refer to the killing of Binaama's brother. The story takes off when Ntare from Burundi invaded Buroha and Busanza (prefecture Butare) and Binaama refused to go and attack them. Next Binaama meets the murderer of his brother whom he eventually kills. This was under king Seemugeshi. He then went to war against the invading Rundi. Eventually he met a poisonous snake the Rundi used for protection.

After divination at the court, a way was found to make the snake abandon the fight. Near its hole the great rock of Shaari arose, where Binaama continued to fight the Rundi the next morning. He then met a Hutu with whom he smoked a pipe and drank, "which is recorded in the poem "Mpiingwe, although you were strong." Binaama went to fight again, was wounded by an arrow, cursed Burundi, and the

\footnotetext{
"For him, Nyagakeecuru lived on Nyakibanda hill southwest of Butare and he does not mention Mubumbaano, which may well be a different hill. Usually Nyagakeccuru is associated with Hutuyi mountain, northwest of Butare. For her name in fiction (ummugani) see the tale from Bugoyi recorded in Jan Czekanowski, Forschumgen in Nil-KongoZivischengebiet : Ethnographie:Zwischenseengebict Mpororo/Ruanda (I.cipzig 1917), 351-5.3.

"Kagame, Abrégé I: 8.5, 109, 110.

"Ilbid., I: 94. No story abour Ndoori's supporters wals found during research for the IRSAC collection, although this was a three-year-long collective effort over the whole conintry of Rwanda.

"Mizimpika, T: \#4.
} 
Rundi were overcome. At the end of the tale, Mugina recalls the saying "We arrive at the place where Binaama saved Busaanza province," which refers to his victory over the Rundi. We are not told whether Binaama died and, while the great rock of Shaari figures in this tale, it is not Binaama's tomb nor is the snake Nyagakeecuru's but it belongs to the Rundi.

Then there is the popular story of Nyagakeecuru and Ndoori." She lived on Huuyi hill and he first gave her goats to keep, as well as chickens. For she was fenced in by impenetrable nettles. Eventually the goats browsed and the chicken dug the roots up and when the fence was gone Ndoori attacked. Nyagakeecuru then expected to seduce him, but he killed her with a blow of his knife and her place was looted and burned. A second version of this story (\#28) is terse. Nyagakeecuru's son was Rubuga, king of Bungwe. Ndoori tried to kill him, but Huuyi was surrounded by a fence of nettles which contained a snake. Ndoori sent goats, who ate the nettles and the snake left, which allowed his warriors to kill Nyagakeecuru and Rubuga. Something like these versions clearly has come into Kagame's reconstruction, although for him Nyagakeecuru was not vanquished by Ndoori. He therefore denies the whole point of the story, which turns around the ruse by which the impenetrable fence was destroyed and also the rulers within. For Kagame this feat should be left for Binaama a generation later and the destruction of the rulers becomes the "conquest" of Bungwe.

Elements of yet another set of versions also appear in the Kagame interpretation. Elsewhere again in the IRSAC collection we find the tale of Rubuga, in which Binama appears and which echoes Nyagakeecuru's story. ${ }^{42}$

Rubuga was a Mwenengwe kinglet [in Butare prefecture]. Ndoori spied on him and had him attacked by his personal regiment, but the warriors could not arrive at Rubuga because his residence was fenced in by impenetrable nettles. Peace was made and Ndoori gave him a herd of goats which began to browse ... Ndoori died and Seemugeshi succeeded. He settled at Mwurire [near Butare]. Binaama of Yuhi, "of whom one hears people speak" attacked and burned Rwaaniro, Akanyana, Maara, Bijeje, Gishyita, Buhoro. Nyagakeecuru's servant saw all of this and reported it in words which are now a popular saying: "We are attacked when Ruganzu had paid bridewealth for Rubuga's daughter to marry her to his child Mutara [Seemugeshi]." Rubuga died in war but the royal drum Nyamibande was saved and hidden. The Rwandese found the drum with the

\footnotetext{
"Ndoori $\mathrm{H} \# 20$ and \#28.See also \#40, which is very close to \#28, as is \#65 and \#67 concluding, "and Rwanda becnme even bigger." Pagès, Royaunie, 282-83, has the same story and assumics that its historicity consists in the conquest of the Hutye area.

12Seemugeshi, T: \#9.
} 
daughter of Kamaganja and brough them to their court. There the fringes of her skirt touched the skin of the drum and it sounded. She said "Nyamibande you left our place when all was destroyed, when Rubuga is dead and yet in Rwanda you sound." Whereupon a Rwandan said "Why should it not sound? if it did not we would not have hit it with iron points." But the girl swelled up and died from grief. When the diviner Mpande [the most famous of royal diviners in all ibiteekerezo ] was told of it, he too died of grief. So had Rubuga and the Benengwe lost their cattle and their goods.

This is a different tale, of course, in which Binaama and Nyagakeecuru merely put in cameo appearances, the point of the story story being the downfall of the Benengwe and their drum. It is in this tale that Kagame found the references to Ndoori, Seenugeshi, Rubuga, and Nyamibande. He adds that a fissure in the drum had been repaired by iron points and that the drum is mentioned in a dynastic poem supposedly composed only two generations afrer Seemugeshi. ${ }^{43}$

So, disregarding the story of Binaama's vendetta and his war against the Rundi, which stands by itself, we have gone here from a tale about the surreptitious conception of a hero who later overcomes a magic fence, is killed and rises as a rock, over to a story focused only on the overcoming of the magic fence on Huwyi, where its remnant can be seen, then to a tale about the capture of a royal drum after the overcoming of the magic fence. Comparison with other ibiteekerezo shows that the theme of a surreptitious conception of a hero occurs fairly frequently, while that of a woman touching a royal drum and dying also occurs in the famous story of king Bwimba and his sister Robwa. The magic fence, however, is unique to this story and linked only to the woman with the nickname Nyagakeecuru. Moreover, the episode about Binaama's death is etiological, as it "explains" the presence of the great rock of Shaari just as Nyagakeecuru's, which explains a feature on Mount Hunyi. If the actors had nor been given names, everyone would dismiss all of these tales as fiction, including etiological fiction, without further ado.

We have therefore to understand how names of supposedly historical personages came to be attached to these stories. Should we assume, as Kagame did and other historians are often wont to do, that the stories are a fictional elaboration of real events-in this case the conquest of Bungwe over the course of four reigns? Or should we assume that the names became tags attached to these stories to give them verisimilitude and, if so, how were these "historical" names actually remembered? In the case we are examining, several situations occur. First the popular tale opposing Ndoori and Nyagakeecuru is

'Kilgannc Abrige, 1:110. 
only one of very many popular tales, often etiological, about this truly legendary king. A comparison of all the tales known makes it clear that this king stands in for the archetypical king of Rwanda and the name Nyagakeecuru hints at magical power. The names are just reifications of "the king of Rwanda " and "the sorceress." The name Binaama meaning "advice, council" is also an integral part of the surreptitious conception episode and so is his later death as a hero, because all the events were planned by the royal diviners.

The mention of Seemugeshi shows another dynamic, that of verisimilitude. He seems to be mentioned only because in the logic of the tale time was needed for the fence to disappear and for Binaama to grow up. Since storytellers knew that Seemugeshi succeeded Ndoori and that in the popular best-known tale Ndoori gave the goats to Nyagakeecuru, the effect had to be delayed and hence the conclusion of the plot had to occur in the reign of Seemugeshi.

But what of Yuhi Gahima? Here we must remember the story of Binaama's vendetta and war against the Rundi-in which he is not killed. The first war against Ntare of Burundi, albeit not the first encounter between the kings of Rwanda and Burundi, in the ibiteekerezo took place under Yuhi Mazimpaka who was then at Rusatira in the prefecture of Butare. It is therefore likely that Gahima came into this tale simply by mistake, for this other Yuhi and indeed in one version at least Binaama dies under Mazimpaka. ${ }^{44}$

If the names of the main protagonists are thus explained away, one still has to account for other personal names which occur incidentally in these tales, such as Rubuga, Benengwe, and even Nyamibande. These seem to be only indirectly linked with the actors of the tales themselves, but directly tied to the locale where the tales occur. The Binaama/Nyagakeecuru tale always takes place in the same area, now remembered as Bungwe, and many hills in it are named in that tale. But the personal names linked with rule over Bungwe are not remembered at all in the common histories about these hills. They apparently derive from another type of tradition altogether, perhaps from a secret inteekerezo, perhaps from a genealogy known at court, or from both, and "seeped" from there into the tales mentioned.

On Kagame's maps, also found in the official Atlas of Rwanda, we

\footnotetext{
"Mazinnaka, T\#4 for Binaama against the Rundi. For the context see Kagame, Abrégé 1:111-13, occurs supposedly under Seemugeshi and mixes two types of information: one about an explanation for the placename utuicara-bami "seats of kings" near Nyaruteja (Butare prefecture) and one secret tradition about the origin of one wbwiiru ritual from Burundi in which the ritual specialist is settled at Rusatira, Butare prefecture. This place is also the later headquarters of Yuhi Mazimpaka (129) in his struggle with "Ntare" as told in ibiteekerezo.Obviously this is the context for this tale about Binaama. Despite its supposed secret transmission among ritualists only, the supposed Rundi origin of a whole ubuviru ritual is not credible. Not only does it contradict ather data, but ubwiiru did not exist at all in Burundi.
} 
find Bungwe generously defined as a conquest of Seemugeshi and dated to 1543-1576.9. By examining these tales we have by chance also surveyed what evidence there is for the conquest of Bungwe by Rwanda. And is it not poor evidence?-tales without historical contents, a set of names stemming probably from the court, and a drum that was kept there. No trace was found by the IRSAC collectors of a tale, cited by Kagame, according to which Seemugeshi was at Rusatira when his cattle were raided by Rubuga, son of Kagogo, from the Abaganda regiment. All the lands of the Benengwe were atracked and the conquest of Busanza, Bufundu, and Bungwe ended with the capture of Nyagakeecuru and her drum. ${ }^{\text {th }}$

Given Kagame's handling of such tales, it is very likely that no such detailed precise story ever existed. although there may well have been a story about a raid on the Abaganda. As to local history, it only tells us that this area was part of Rwanda by the time of Gahindiro (ca.1800) and perhaps by the time of Rujugira (after 1750). All one can say then is that Bungwe became part of Rwanda at an unknown time before 1800 , perhaps even before 1750 ! One might also add that, as far as is known today, Bungwe was the first foreign land occupied by the Nyiginya kingdom after it had settled in Nduga just to its north, well before any other "conquests." We stress this conquest story because it is typical. Most of the evidence adduced for any early conquest in Kagame's writings or on his maps is just as flimsy or even more so. In the atlas Bungwe is already "conquered" in the fifteenth century, along with the whole west and north of Rwanda, Kigezi district in Uganda, and a large swathe of North Kivu! It is all arrant but dangerous nonsense.

Let us now close our discussion of the two tales about Yuhi Gahima in the IRSAC collection. The conclusions are obvious. The Nyantebe type of tale has historical content, even if it is only a list of powerholders, whereas the Binaama/Nyagakeecuru story has practically none. Yet the latter has been very useful in drawing out some of the characteristics of the ibiteckerezo in the strict sense, and especially to show how unreliable the existing reconstructions of early Rwandan history are. We also observe that neither of the two tales tells us anything at all about Yuhi Gahima. As far as this collection is concerned, we merely "know" his name which also occurs on the dynastic list of rulers and the name might stem from there. True, Mugina provides more information at the end of his account about Matama, Gahima's supposed mother. He says that Gahima killed a buffalo near the Nyabarongo, whose tail was in the royal trensury

\footnotetext{
"Kagame, Abrégé, I:38 (date) and map, 3; A. Kag:ame in C.. Prioul, P. Scrvetl, eds. Atlas du Ruanda (Kigali), 1981 : xii/2.

4"Kagame, Abrégé, I:109.10.
} 
and adds: "the only land that I know which he added, is Bwishaza, Nyantango, and the whole of this land above Rubengera." 47

But this is not a narrative, and the information seems to be derived from Kagame, whose Inganji Karinga was well-known to Mugina. Kagame does provide this information. ${ }^{48}$ He claims that Yuhi Gahima made extensive conquests west and north of the Nyabarongo river, as well as in lands north of lake Muhazi. But this is flatly contradicted by all local history, and by the claims (whatever they are worth) made by later kings, especially Rwabugiri (ca.1865-1895) that they first conquered these areas. ${ }^{49}$ We are only left with information as to where he (and all Yuhi) and his mother were buried, and even that is not above suspicion. One can thus reasonably object to Kagame's statement that "Yuhi II has not only been immortalized by the Tales of the Memorialists but his existence is supported by much testimony, which one cannot reasonably reject," if only to point out that he has not been immortalized by these tales and that we know nothing about his reign. "In fact one inight doubt whether he ever existed. Even at least one storyteller, Mugina again, voices the doubts of some and tries to refute them: "This is not ... the stories that go around are not fictional tales, they tell what happened. I am telling you it happened in this way because there are visible signs which people use to convince themselves of it." $\$ 1$

What the IRSAC collection has done in this case is to draw attention to the lack of narratives about this ruler and hence to throw doubt on his existence. And Gahima is not the only ruler for whom no evidence exists and whose very existence can be doubted.

\section{V}

Ibiteckerezo can be studied for different purposes and each purpose requires a different sort of analysis. Historians focus on them as pos-

\footnotetext{
${ }^{47}$ Mutalsanzi, T: \#3: 14-15

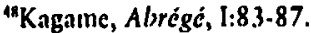

4"This is particularly striking with regard to Nzaratsi in Nyantango, where Yuhi Gahima was supposed to have founded a major capital. Local history stresses that this capital was founded by Rwabugiri "in 1893." Cf. Historique et chronologie du Ruanda (Kigali, n.d.[1956]), 11.3 (data from 19.35-39). Until that time the local lincages of both pistoralists and farmers only obeyed their local chiefs.

"Kagamic, Alrégé, 1:87.

"Mutabanzi, T\#3:14. The proof consisted in a buffalo tail in the court treasury at least until Musinga (1896-1931). Gahima had killed this buffalo at a spot near the Nyalarongo across from Budaha. Mugina concludes: "Therefore it has happened, we know it." A critic might object that a buffalo was supposedly killed near the Nyabarongo by an earlier king, Mukobanya, during the campaign against Murindaand why would this tail not commemorate that feat? Cf. Kagame, Abrégé I:67. Kagame omits to say that this detail is part of the story of Murinda, for the buffalo was magically linked to Murinda so that only when it was killed could he also be killed.
} 
sible sources and should therefore apply the rules of evidence to each tale they want to make use of. Unlike many other authors, they will not assume that ibiteekerezo are essentially straightforward, although embellished, reports about past events, or as Pagès put it, "details fantaisistes, mais fond historique." $\$ 2$ Such an attitude will not do because it disregards two essential features of these tales, namely, first that they are products of Rwandan culture and therefore steeped in its worldview, and secondly that they were entertainment. One should remember that this entertaininent presupposed a set of specific Rwandan assumptions about the world in which the invisible ruled, fascinating all precisely because of its invisibility. Fate was everywhere and divination could uncover it, ennemies were first defeated by magic and only later in the visible world, august persons killed in war always were "really" voluntary sacrificial victims, called "liberators" and their death assured victory unless more powerful ennemy liberators countered them. One should not just dismiss all this as "impossible" or "embellishment" but keep in mind that such Rwandan perceptions of reality did in fact dictate actions. There really were diviners and contests of magic, and princes or kings killed in war might have been thought of, after the fact, as "liberators."

The historian should never forget either that true ibitcekerezo were told as entertainment. Hence tales setting a prophetic riddle and then explaining it, romances about royal marriages, conrests of magical strength and the like. Some credible historical information may well be embedded in such a tales, as we shall see, but this is not even always so. Besides these classic ibiteckerezo one also finds straightforward reminiscences. But, however interesting from the historian's point of view, these were entertaining only when they dealt with a recent past shared by the audience or its parents, such as an account of deeds accomplished under Rwabugiri. As to narratives which are thinly disguised part genealogies and assertions of historic rights over land, these were certainly not entertaining but were remembered as an exposition of legal claims. One cannot just strip them of the more obvious implausible details and accept all the rest, a rather arbitrary procedure. Rather, one must apply the rules of evidence. Central to this historical critique will be the fact that ibiteckerezo are tales to edify or to amuse. Hence their literary analysis will be perhaps the most crucial element in their evaluation as evidence. As it happens, few historians are familiar with the critical use of the literary analysis of oral narratives. Hence, rather than discussing once again wellknown rules of evidence as they may apply to ibiteekerezo, we address only this type of analysis. This is followed up with a second partly unfamiliar issue, but typical for ibiteckerezo and crucial for

'plagès, Roy'aume, 57.5 . 
their critical evaluation, namely, the issue of implicit dating which depends on the reliability of the link between a specific royal actor and a tale. Ultimately, the chronology of the whole corpus of ibiteekerezo and all of its elements derives from the list of dynastic succession and each tale is placed in time by its link with the name of a king.

First one examines the very point of the narrative or its main message. A narrative may be completely fictive, but its point might have historical value. Thus the story of how Ndabarasa, instigated by some abiiru, tried to convince his father Rujugira to rebel against his brother, the ruling king Rwaka, but failed, whereupon Ndabarasa attacked the king himself and put Rujugira on the throne, may well be entirely fictive. But its point is historically significant: namely that Rujugira came to power in a coup and not as all other narratives about this have it-as the rightful preordained but overlooked heir of Mazimpaka."s The point is all the more credible in that the alternative tales about this story are patently self-serving to bolster the court's point of view that a coup never happened in Nyiginya history.

Moreover, in this case two other assertions in the story might well be credible too, namely, that it was not Rujugira but someone else who actually carried out the coup for him and that Rwaka was not killed but relegated just outside of the kingdom in Budaha province. The credibility of these assertions derives in part because they go against the usual expectations: usually the one who leads a rebellion becomes king and a defeated king is killed. In part, their credibility derives from the fact that these assertions are also made in other not directly related narratives about this event. ${ }^{\text {s4 }}$

Etiological tales about customs are especially prominent in ibiteekerezo because they established a precedent and thereby legitimized the custom. Moreover, because Rwandans believed that Fate caused history, precedent also sacralized custom. Some etiological tales, such as the Rwaka story, are reflections on history and useful to establish different points of view in its interpretation. Often though, the main point of a tale or some accessory one in it is etiological. Thus, in this story the proof that Rwaka was not killed is that most of his descendants live in Budaha. Kagame, like many narrators, thinks that such etiologies prove the "truthfulness" of the tale that reports them. Indeed he calls such traditions "vital traditions" as opposed to "oral traditions" and ascribes such credibility to them that he lists them for every sovereign before Mazimpaka as absolute proof that such and such a king ruled and did such and such things.s.

\footnotetext{
"Mazimpaka, T \#10. Compare to T \#9 and to Kagame, Abrige , I:130-31, 133-34, for the same sequence but different explanations, in which Rujugira was the rightful successor.

"See preceding footnote and A. Des Forges, "Court and Corporations in the Development of the Rwandan State," ms. n.d. (ca.1984?), 19.

"Kagane, Abrégé I:9-10 et passim"
} 
But he is clearly mistaken. Most etiological tales are explanations dreamed up after the fact and hence especially untrustworthy. For example, king Ndoori is said to have fled from his enemies into a cave, where he found monkeys who then excavated another exit for him, which explains why a live monkey was always kept at the royal court. ${ }^{56}$ Indeed, the same tale similarly explains the presence of important Twa servants and Twa privileges at court, as a reward for the devotion of a servant of Ndoori in the same cave. This servalt asked to be henceforth called Twa and have the privileges in question. This is one of the many examples in which a tale is not just etiological but underpins the existence of a privilege or a sanction. Most of these tales are of extremely dubious value. Yet Kagame used one of these as a paradign of his vital traditions. Descendants of Mazimpaka may not now marry wives from the Cyaba clan, and according to the tale Mazimpaka imposed this sanction on his Cyaba wives because they had disobeyed him by hiding king Nsoro of Bugesera. ${ }^{57}$ But in the Pagès tale, Mazimpaka's wives had slandered him; in the IRSAC collection Mazimpaka jumped from a rock and was killed in pursuit of Cyaba maidens, or his Cyaba wives used poison to make him insane, or his wives slandered his son Musigwa, whom he then killed. In a story about Mutabaazi, he punished his Cyaba wives who had dared to ask him who his successor would be by forbidding any Cyaba woman ever to become queen mother. ${ }^{s x}$ Moreover, Sinith points to similar Nyoro and Nkore stories, where the Singo clans was ostracized because of the bad behavior of royal wives of that clan. ${ }^{5 y}$ The motif then is a cliché and not even always linked to Mazimpaka. Still, from all the available versions, including Mazimpaka's, it is evident that the cliche has been inserted wherever it seemed appropriate. In the end one merely learns the only thing that what was already known: that the descendants of Mazimpaka apparently did not marry Cyaba wives!

Sometimes an etiological explanation points to an archaic privilege which no longer exists, and one would therefore be tempted to give credence to such a tale. That would be an error for often enough such a story only expresses today's wishful thinking. Thus Rugwe is said to have proclaimed the right of herders to pasture their herds anywhere, on any land, cultivated or not, a blessed privilege from a pastoralist point of view. This tradition was jotted down in the 1920s, when this supposed privilege had been denied for many generations. " What the

\footnotetext{
"Pagès, Royaume: 26.3-66.

"Kagane, Abrégé I:10, 127.

'Pagès, Royaume, 138, Mazimpaka H \#4, \#9; $\mathrm{T}$, \#8, \#12. Mutabaazi, $\mathrm{T}$ \#

"P. Smith., "Personnages de légende" in La civilisation ancienne des peuples des grands lacs, (Paris, 1981), 246-47.

"'Pagc̀s, Royaume, \$26-27.
} 
tale actually shows is that just then some powerful herders at court were trying to obtain such a privilege! Yet sometimes etiological explanations can add something of historical value. Pagès tells us that the Nyiginya, the clan to whom the rulers belonged, was originary from Muhima, a "sacred" well near Kigali, no doubt because the name of the well refers to the Hima social category. While dismissing this as an etiological tale without historical value derived from the name of the well, one should still note that it implies that in the 1920 s the Nyiginya at the royal court were believed to be of Hima, not ancient Tuutsi, origin, a point which belies the usual official claims and shows how even by then the Tuutsi and Hima social categories were in the process of merging. ${ }^{.1}$

Having analyzed the message of a tale as a whole, one then examines its plot and constituent episodes more closely. Is the record there really the record of an igiteekerezo at all? In the IRSAC collection several pieces clearly are not. One of its Mazimpaka records goes as follows:

King Mazimpaka lived at Juru of Kamonyi; compared to other kings he surpassed them in various ways. Especially when it comes to poetry ... and moreover he had the gift of prophecy. He foretold many things. Note that one day he even foretold the coming of the Europeans . . . King Mazimpaka rises above other kings through the fact that he yearned to have inventive minds and poetic souls among his councillors. He had near him such persons who lived at his expense ... Thus any expert in Mazimpaka's time exclusively exercised such activities as were his profession and his livelihood.62

Certainly an eloquent case of special pleading in 1958 by Raphael Ntuuro, a reknowned performer! But this declaration obviously is not a tale, but only a personal opinion about this king, based no doubt on his overall knowledge of oral traditions. And it is an account of those the historian wants.

Once it is clear that a tale is an igiteekerezo one examines its plot and episodes for originality by comparing them to other tales. By definition an igiteckerezo is different when its plot differs from others. But on occasion plots can be very similar. Thus the overall plot of the secret marriage and abduction of Nyanguge is quite similar to one about the marriage and abduction of the wife of Murari of Ndorwa, aithough the personages differ. ${ }^{6.3}$ In this case the second one is a

"Ilbid., 561, 573. Schumacher, Ruanda, 160 hears a difference in tone and rejects the etymology of Pagès.

"2:Mazimpaka, T \#7.

"All versions of Nyanguge are filed under Rugwe and Mukobanya; Murari under Murnbanzi, H \#7 T 10, both by Seebuhoro. The child of Murari's wife was even called Kigeri, like Nyanguge's child. But Murari also occurs under Ndabarasa, H \#22. The child was also called Kigeri (Ndabarasa), its farher Cyirima (here Rujugira). 
calque of the first, not because only one storyteller told it, although that is certainly an indication, but because the child in both tales was called Kigeri. This fits with Nyanguge, as Kigeri Mukobanya supposedly succeeded Cyirima Rugwe but not with Murari's wife, as no Kigeri succeeded to Mibambwe Mutabaazi. In addition a very similar but not identical plot also occurs as part of the plot of the famous Matama story - and to a lesser degree in the Bwiza stories. ${ }^{64}$ The latter is in fact a fictional tale (umugani) and Smith included a beautiful version of it in his collection. ${ }^{6.5}$ This plot or part-plot clearly stems from fiction and contains no historical information except perhaps for the fact that king $X$ married $Y$.

As to the borrowing of episodes, the story of Nyanguge gives a striking illustration, which follows. Each episode is numbered and followed in parentheses by parallel episodes in other tales.

1] Rugwe, the Nyiginya king, has children but no heir (also Matama).

2] He isolates himself, mopes, and attacks his faithful councilor who comes to enquire, but the councilor dodges the attack (also Matama; also Ndoori with his councillor Mushenyi in Pagès, Royaume :307-08).

3] Divination tells the king he must marry a princess from afar ( also Matama).

4] But the princess had a previous royal suitor to whom she had been promised (Murari's wife, Bwiza, and some versions of Matama)

5] She is married to the other king, but the Nyiginya king manages to bless her and to consummate the marriage first.

6) Nyanguge boasts to other wives that she had two kings in the same night (Matama; Mashira)

7] Her secret discovered, she is forced to flee (Murari's wife, Bwiza, the sister of Nyagakeecuru).

8] She is brought to a new capital unknown to the Rwandan court (Matama, Gahindiro).

9] Her son grows up in isolation at first, then overcomes other claimants to the kingship and rules (Matama, Mazimpaka, Gahindir(s).

All these episodes are obviously mere literary devices, just as dialogues or standardized descriptive imagery are, and they are not historical. Sometimes parallels are due not to a general literary device but refer to a specific symbol whose precise meaning has been lost. Thus three successive kings-Ndahiro, Ndoori, and Seemugeshi-all belonging to the same cycle of "legendary kings," and all wounded in the eye. This caused the death of the first two, while the third recovered only by taking on a new dynastic name "Mutara" although in

".'Both filed under Mutabaazi.

"Sinth, Récit, 29, 76, 290-313 \#17: 
one different tale he also died. ${ }^{\text {th }}$ Not only can one not accept any of these claims as historical, but one cannot even understand what to be wounded in the eye actually implied.

Borrowing episodes or descriptions was not limited to Rwanda. Thus the wildness of hairy Ndahito, a newly-arrived stranger in Bugoyi and the disguise of Ruganzu dressed in sheepskins in order to kill his enemy, are both prominent in the stories about Ntare Rushatsi, the first king of Burundi and have been borrowed from Burundi, as they do not carry the symbolic load in Rwanda which they carry in the Ntare story ${ }^{67}$. And we have already mentioned Nyoro and Nkore stories about a clan ostracized because of some royal wives.

Nevertheless, the case of Nyanguge is rather exceptional. In most ibiteckerezo, especially those pertaining to kings after Mazimpaka, most episodes are unique and one can accept that they reflect a good deal of history. The tales about the conquest of Gisaka in the $1850 \mathrm{~s}$ under king Rwogera are a good example of this: Gisaka had been fractured into three chiefdoms after the death of its king. One of the chiefs, Ntamwete, claimed the throne and was recognized by a second one Rusheenyi. But as Ntamwete began to assume direct control of four named hills from Rusheenyi, as well as many cattle, Rusheenyi fled to $R$ wanda. Hitherto it had been nearly impossible for Rwandans to invade Gisaka because the road into Gisaka went between impenetrable marshes through a forest which had always favored the defense, but Rusheenyi showed them another road crossing the Nyabarongo, which then allowed the Rwandans to raid and then occupy the country. ${ }^{6 .}$

On occasion even parallel episodes in different tales may well refer to some historical event. Thus Sentaabyo was said to have been killed by smallpox (ca.1800), the germs of which were hidden in a piece of barkcloth offered to him by an enemy as a gift. But the same story is also told about a Nyoro or Nkore king. Moreover, Rwanda's king Rwogera was also supposedly killed by a tobacco pouch infected with tuberculosis germs. ${ }^{69}$ The episode itself is not credible, but perhaps Sentaabyo did die of what was believed to be smallpox and Rwogera of tuberculosis, so that the cliche could be applied to them.

The last literary question to consider deals with the vexing ques-

\footnotetext{
"Scemugeshi T \#7.

"In addition to files Ruganzu, see, e.g., Pagès, Royaume: 246 (Rusatsi); 278 (dressed in sheepskin is Cambarantama). For Burundi J. Vansina, La légende du passé:traditions orales di Burundi (Tervureli, 1972), 81-84. Neare's personal name was Rushatsi. See also J-P. Chréticl, "Du hirsure au haınite. Les variarions du cycle de Nrare Rushatsj, fondateur du royaume du Burundi" HA 8(1981), 8-12.

"Rwogera $\mathrm{T} \# 14$ and $H$ \#7. Compare with $\mathrm{T} \# 2$, more colorful but less precise.

"Kagame, Abrége 1:168-69; Rwogera T \#3 ; 13; 4.
} 
tion of the competence of the storyteller as revealed in the tale. Has the tale been competently told as a tale or is it a garbled, mixed-up rendering by an ill-informed person of several tales he heard, in which case it is highly suspect. Smith has forcefully argued against the usual view that all the versions of a tale are equivalent and must all be considered when evaluating it. While this is valid enough in most cases, there are incompetent story tellers. and once one collects over fifteen or thirty haphazardly collected variants of a rale or a set of relared tales, such misfits stand out. Such accounts should simply be dismissed. "

This is as true of ibiteekerezo as it is of other tales. Hopelessly confused versions are very rare in the IRSAC collection and are easily recognized. They stand out by a flawed technique in the story-line of the tale, by confusing actors, and by mixing up several otherwise totally unrelated narratives. In one such case the storyteller betrays himself from the outset by frequent hesitation and fractured sentences. His long performance is incoherent and too confused even to summarize properly. The tale is supposed to be about king Rugwe. It begins with bits of several ibiteekerezo concerning Bwinba and the designation of his heir, Cyirima Rugwe. He then promptly mixes him up with his much later namesake Cyirima Rujugira. From then on parts of various ibiteekerezo concerning Rugwe, Mukobanya, Rujugirn, and Ndabarasa all jostle ench other without any consistent storyline until the performer hits on the story of Gihaana's death in Burundi, develops this at length, and ends with a tale of how Mwezi of Burundi (actually Mutaaga!) was then killed in Rwanda to save Burundi from a terrible drought. He is so bad that he even does not notice that he has his "Rugwe" ruling twice."

Should one simply dismiss this disastrous performance out of hand? In one sense, obviously yes, because it adds nothing new. The performance begins only to have some meaning when one has identified the numerous different ibiteekereezo which are included in it. At that point each bit in the performance becomes a variant of the tale which it summarizes, alludes to, or recounts and can be handled as such. But in another sense the confusions which occur in this and other cases are precious because they reveal something about the recurrent ways in which confusions occur and hence new stories are born. Mixing up names of actors and with them stories attributed to these actors is the most obvious "dynamic of error:" Much less common is the sliding from one tale to another by confusing similar episodes in the two.72

\footnotetext{
"Snith, Récit, 19-20.

"Rugive $\mathrm{T} \# 4$.

7'But see Ndabarasa $H \# 8$, about Nirabiyoro, where the first episode is taken from the Nyalgakeecuru storics.
} 
Finally it is not enough to compare episodes or plots of different ibiteckerezo. One must also pay attention to larger groups or cycles linking various ibiteckerezo together. In some versions a subtale links two plots together into a larger whole. Thus the story of Bwimba's death is sometimes linked to the Nyanguge tale by a subtale describing the avenging of Bwimba by his councilor Mukubu. ${ }^{3}$ Historians should take such cycles into account because they help to evaluate the historicity of an individual tale. Thus Kagame used the argument that the tale about the death of Ndahiro and the destruction of the royal drum must be true because it reflects a disaster that normally would have been suppressed. ${ }^{74}$ But the reigns of Ndahiro, Ndoori, and Semugeshi are all interconnected and form a cycle in which the death of Ndahiro has to be a disaster in order to highlight the achievements of his successor Ndoori.

\section{VI}

All ibiteekerczo raise two different issues of dating: the date of the performance recorded and the date at which the events narrated supposedly happened. In the IRSAC collection the date of performance is given for each tale. It is primarily relevant when one examines detailed descriptions, attitudes, and opinions expressed about social or cultural life. The tale was composed before this date and presumably some time after the date of the events narrated. Sometimes one can say a little more. In the case of prophecies, for instance, one deals with a veritable subgenre of enigmas. The structure of such a tale by itself is not historical: the prophet sets the enigmas and the tale solves them. The composition of each historical prophecy, however, must date from a time after it came true. Thus those prophecies at least in the tales about Nyirabiyoro or Mazimpaka, which allude to the reign of Musinga, must have been composed only after 1896 , a century or more after the supposed lifetimes of their protagonists. Indeed in one case a performance recorded early in 1960 already contained a prophecy about Kigeri Ndahindurwa crowned king only in July $1959 !^{75}$ Prophetic tales tell us practically nothing about the times of the protagonists but they still can contain important historical information. Thus the Nyirabiyoro prophecy that marshes would begin to be cultivated under Rwogera, is an assertion about Rwogera not recorded anywhere else. ${ }^{76} \mathrm{~A}$ crucial part of a performance about Mazimpaka's prophecies specifies that, of the five kings following him, three would have short reigns and specifies these to be:

"Rugwe, $H \# 1$ : \#5; T S, alludes to this vengeance.

"Kagaıne, Abrégé 1:91-92.

"Ndabarasa, H \#10: 2

"Ndabarasa, $\mathrm{H} \# 10: 2$ 
Sentaabyo, Gahindiro, and Rwogera and adding for good measure Rwabugiri "who died in full youth." tions about the lengths of reign of these three kings, which in itself is quite valuable because it shows that the "usual" view was not unanimous after all.

Feedback should also be mentioned in this context. A classic example here deals with the story of the Nyoro invasion whose leader was supposed to have been Cwa of Nyabungo. Pagès was not told any royal Nyoro name, but the name occurs in Kagame's Inganii Karinga (1943) and in his later works. He took the names from a book published by Gorju in 1920, as that "had to be" the name of the invading king. The usual name in the IRSAC collection however, when one is given, is "Rubiito son of Mucweezi" (Biito is the name of the Nyoro dynasty) and this is also the name in Schumacher's account. ${ }^{7 x}$ Still, two performances mention "Cwa son of Nyabungo" and thereby clearly show feedback from Kagame's Inganji Karinga on this point. This in turn renders their whole tale-and even their whole repertoire-suspect of having borrowed from Kagame's works and therefore to be dependent on the credibility of his material. ${ }^{7 y}$

In only a single case so far can on actually date the composition of an older tradition to a particular reign. The best-known tale about Seemugeshi narrates how he was given a new dynastic name Mutara. But according to Kagame, a secret commentary of the abiiru added that it was at this time that the rules about the succession of the regnal names in cycles starting with Mutara or Cyirima was laid down." One can prove that at least the secret commentary does not date from that time but from the much later reign of Rujugira. Rujugira's predecessor took the regnal name Karemeera, which does not occur in the cycle and therefore the rules about cycles did not exist. But as Rujugira' s corpse was not buried but was kept smoked above ground in accordance with these rules, these existed at his death. It is an important finding because it means that, before Rujugira, regnal names

\footnotetext{
"Mazimpaka, T \#3: 4-5. Rwabugiri died at the ane of forty or less; sce F. Van Noten, Histoire archéologique du Rivanda (Tervuren, 1983), 102.

"Xschumacher, Ruanda, 161. He wrote this text prohably in the carly 1930)s. His sources were major specialists in history at court and he was a very carcful scholar. Hence it is practically certain that the cours had never heard of a "Ciwa of Nyabunge" by then. Schumacher understond these "Nyoro" to be Hinda from Buhay:l and not warriors from Bunyoro.

"Pagcis, Royanme 5.58-61, 570-73; Kaganc,Abrigei I:71-72. Files Mukobinya and Mutabaazi. Only H \#3. and Mukobanya $T$ \#1:12 have "Rubiito, son of Mucweeg.," feedlanck only Mutabaazi T\#11 (Louis Ntuuro) "Cival of Nyabungo" and, even more flagrantly, Mukobanya T\#1 (Jean Mugina) "Civa of Nyalbwoogon." Mugina and Neumro were anong the most prolific storytellers in the IRSAC collection, but they also knew their Kagame very wcll!

"Kagame, Abrégé, I:113-15.
} 
need not have occurred in cycles at all, but that court officials might well have attempted to complete such cycles from isolated regnal names, probably by adding the missing regnal names in a sequence.

The second date is crucial for the internal chronology of the kingdom. It is indicated by the attribution of a tale to the name of a king and the succession of kings is known from the ubucuurabwenge, the tradition containing the official dynastic list. In many cases the links between king and tale are so strong that naming a king immediatedly evokes certain ibiteekerezo, as one sees in the case of confused performances. Nevertheless, confusion between kings can occur, with the result that some tales are then attributed to the wrong period. The main cause of error is the recurrence of the dynastic names, which occur in cycles, especially those of Cyirima or/and Mutara, Kigeri, Mibambwe, and Yuhi. Examples of this type of confusion have already been noted. Other examples are the confusion of CYIRIMA Rugwe and CYIRIMA Rujugira;" MUTARA Seemugeshi and MUTARA Rwogera;"2 MUTARA Seemugeshi and CYIRIMA Rujugira; ${ }^{k 3}$ KIGERI Mukobanya, KIGERI Nyamuheshera, KIGERI Ndabarasa and KIGERI Rwabugiri;"4 MIBAMBWE Mutabaazi, MIBAMBWE Sentaabyo, and MIBAMWE Gisanura; ${ }^{\text {*. }}$ YUHI Gahima and YUHI Mazimpaka;" and YUHI Mazimpaka and YUHI Gahindiro.,7

Lesser confusion occurs between famous kings, such as between Rujugira and Gahindiro over Rugaaju rwaa Mutimbo, ${ }^{\text {k* }}$ Mutabaazi and Gahindiro, ${ }^{89}$ or Ndoori and Mukobanya, ${ }^{911}$ or even Ndoori and Rwabugiri. ${ }^{91}$ The latter at least was a wilful ploy by the court to jus-

\footnotetext{
${ }^{21}$ at Gaseke, See Pagès, Royamme, 121, 525-26. Another suspect parallel between the two includes their supposed longevity.

"Over Burundi.

"This concerns a pact beween the kings of Rwanda and Burundi. Pagès, Royanume, 132-33; Kagame, Abrégé, 1:111; Rujugirn, $T$ \#1. In this file \#2, but 2 attributes it to Mutara (Seemugeshi) but the Rundi king was Mutaaga, who fought Rujugira.

"For Nyaumuheshera and Rwalugiri see DNewbury "Trick Cyclists? Recontextualizing Rwandan Dynastic Chronology," - HA 21(1994\}, 91-217; Ndabarasa and Rwabugiri $H \# 31$, where even the arrival of Europeans which occurred under Rwabugiri in 1894 is ascribed to Ndabarasa; Mukobanya and Ndabarasa in Pagès, Royaume, 1.36, 143, where the war against Murinda is attributed to Ndabarasa, rather than Mukolsanya as ii most other versions. Pagès records that Murinda was already there at the time of Mazimpaka, which could be a confusion between that king and Rugwe.

"Pagès, Royaume, 81-82, and Gisanura $T$ \#1. For confusion affecting Mutalsaazi and Gisanura see Murnbaazi H \#1,3: 3 (“his son was ... Mazimpaka").

"Gahima T\#8, and Mazinpaka H \#13 about Binanma; also Mazimpaka T \#2 confusion with Gahima.

"See note 91.

"lagès, Royaume, 641.

"About Matama, nlways associated with Mutabaazi, but see Gahindiro H \#24.

"Over Murinda "The Goyi," usually linked to Mukobanya, but see Coupez/Kamanzi, Récits, 2.33 with Ndoori. Also see note 8.3.

"In their polemic inTemps Nouveaux of 8 June 1958, the great "Abaragu" say: "History stares that Ruganzu (Ndoori] killed many Bahinza (kinglets). He and our other
} 
tify Rwabugiri's attempted conquests in the west by claiming that he was just recovering lands already conquered by Ndoori. Confusions between successive kings occur less often. Thus there is a case involving Gisanura and Mazimpaka involving the rendering of justice. ${ }^{42}$ The prophecies uttered by Mashira, usually linked to Mutabaazi, are sometimes attributed to Mukobanya. ${ }^{y 3}$ And the foundation of the capital Nzaratsi is attributed to Gahima or Mutabaazi. ${ }^{94}$ Other cases of confusion between different kings are also rare. Still, there is the bloodpact between the kings of Rwanda and Burundi, usually attributed to Seemugeshi but also and more plausibly to Rujugira." Finally, the case of the prophetess Nyirabiyoro is usually linked to Ndabarasa, but at least once to Gahindiro."

How should one cope with such confusions? How does one know to which king a disputed tale should be attributed ? In practice it has been found that most of these cases are easily resolved by using the following guidelines. First it is evident without other evidence to back up their declarations, that no credence should be given to storytellers who are obviously confused in general. Secondly, subsidiary evidence such as lists of successors or genealogies often provide an answer: Binaama is linked to Mazimpaka, not Gahima, because the genealogy of his descendants fits only with the former. ${ }^{y 7}$ We know that the king buried at Gaseke was CYIRIMA Rujugira and not CYIRIMA Rugwe since the king was only buried in 1932, about a century and half after his demise. If it had been Rugwe, the corpse would have had to be preserved for well over three centuries. And where then was Rujugira buried? ${ }^{48}$

kings have killed the Bahinza and thus acyuired the lands of the Bahuru rule by the Bahiuza." Note the focus on Ndoori, rather than Rivabugiri.

"2. Attributed on the basis of a proverb to Gisanura by Kagame, Abrégé 1:12.3, but very probably to be attributed to Mazimpaka, as in Pagès, Koyaume, 136, because his name ineans "to finish the litigation" (impaka). Further confusion on the same topic occurs between YUHI Gahindiro, YUHI Mazimpaka and Gisanura. Pages, Reynamme, 148; Kagame, Abrégé 1:12.3; and Gahindiro, $T$ \#6.

"Pagès, Royaume, 81, 122, 561-76.

"Kagamc, Abrégé I:83, 84 (Gahima); Pagès, Royaume, 578 (Mutabanzi).

"Pagès, Royaume, 133, and Kagame, Abrégé I :111, favor Seemugeshi. But sec Rujugira T \#1. As CYRIMA is equivalent to MUTARA, this case can le perceived once again as a shift between kings with the same dynastic name. In addlition Caskinnowski, Ethnographic, 290, mentions that Rwabugiri and the king of Burundi "made a pact of friendship," which may or may noe refer to a bloodpact. Rundi sontecs do not mention this, however, so that in this case might Rivalugiri be mistaken for Rujugira?

"Giahindiro $T$ \#2.

"Mazimpaka $T$ \#8. L. Delmas, Généalogics de la noblesse(les Batutsi) du Ruanda (Kalogayi, n.cl. [19.50s]), 48. The genealogy comprised only six generations after the founder to ca.1950 and Mazimpaka lived eight generations ago, while Ciahima supposedly ruled six generations before that.

"Only Pagès, Royanme, 121, 125. ascribed this tomb to Rugive. For the corpse sce Van Noten, Histoire archeologique, $38-4.3{ }^{\mathrm{H}} \mathrm{C}$ dating is $1700+1-90$ and not very reliable). 
Thirdly, an attribution to the earlier of two or three kings is usally incorrect, given the importance of precedent in Rwandan thought as a means of legitimacy. As a general rule one should accept that when the same events occur twice or more, they occurred only during the reign of the latest king to whom they are attributed, and have been "backdated" to provide legitimacy. This is certainly true when supposed conquests are considered. For example, the Nyantango area around Nzaratsi had supposedly been conquered sucessively by several kings. Yet before Rwabugiri there was no trace of Rwandan control and one must attribute the occupation of the area to him. Finally, it is an error to favor automatically the solution that is given by a preponderance of versions, however great, because of that preponderance, since a change of opinion at the court suffices eventually to produce this result as the omissions of kings Rwaka and Rutarindwa shows.

The resolution of these confusions reveals that there are two kings who are not connected to any tales-Gahima and Nyamuheshera. As there is no evidence about their very existence other than the official dynastic list of kings, these people, if they existed at all, may never have been kings. One version of the list, however, mentions that Gahima died young, and there is doubt about the age at death of Nyamuheshera. ${ }^{y y}$ Still, they are mentioned in that list, a source which no author has ever challenged, no doubt mainly because the list has remained unchanged ever since it was first recorded on paper in the 1920s. Yet Pagès mentions in a note about the mother "of a Cyirima or a Mutara" that "a chronological order is lacking for several others [kings]. ${ }^{\text {tow }}$ There is a good chance that these names were made up in order to complete a cycle. Thus Yuhi Gahima ("the Hima") completed a first cycle, while Nyamuheshera completed a second one.

\section{VII}

Let us now look at the collection as a whole to determine the overall profile of ibiteckerezo in the strict sense. To do this makes sense since many storytellers know many tales and have developed an overall his-

\footnotetext{
"Schemucher, Ruanda, 111-12.

1"'Pngès, Royaume, 95-96, taken from the official keepers: r 73-74 (before 1928); Delmas, Généalogies, 23-25, recorded in 1921 from Sharangabo, brother of Musinga and identical with Kagame's. Schumacher, Ruanda, 122-34 (three lists recorded in 1928 and 19.33). Kaganne, Notion, 15, had his list from Rwanyange, whom he says was the single official kecper still alive. For variability in this list see Czekanowski, Ethnographic, 288; Pagès, Royaume, 530, Kagame, Notion, 14. Early attempts to obtain a list from Musinga failed because of the secrecy surrounding it. Schumacher, Ruanda, 122 (he gor six names ca. 1910); Czekanowski, Ethnographie, 286 did not get any information in 1907.
} 
torical representation which encompasses the whole history of the kingdom. 'I'I Even though this collection does not contain examples of all known tales despite our efforts, the great majority of them are represented in it so that one can use it as a representative corpus of the whole courtly narrative tradition. A comparison with other published tales or summaries yields a few new tales. ${ }^{1112}$ As the collection contains only a small fraction of local narrative traditions, however, we can merely use these as illustrative of local traditions in general.

A look at the overall profile of the IRSAC collection shows dramatic differences between the number of different stories told about different kings. As our examination of the two stories attributed to Gahima shows, there are problems in precisely quantifying this information. Should Gahima count for 3, 2, 1, or 0? Hence no misleading summary table of precise numbers is provided for each king. Nevertheless, the amounts vary considerably. The largest number (well over 100 ) of different stories is told about the last precolonial king Rwabugiri, and the least about kings Gahima, Nyamuheshera, and Gisanura (say 1, 2, or 0 for each). But we do not find a steady increase from the first king Bwimba to Rwabugiri as would be expected if the difference in numbers were just a question of the gradual loss of collective memory over time. Other factors are at work.

Going backwards from Rwabugiri, the numbers drop gradually overall as far as Mazimpaka (earlier eighteenth century), with slight rises and falls by reign which can be attributed to a very short period of rule (Sentaabyo) or a particularly long or active one (Rujugira, Gahindiro). Then suddenly, before Mazimpaka there ate only two, one or no ibiteekerezo per reign, until one reaches Seemugeshi, the successor of Ndoori. Along with Rwabugiri, Ndoori is the best known of all the monarchs, even beyond present Rwanda. He is the hero of a host of stories (at least two dozen). ${ }^{11.3}$ Some of these "spill over" to the reigns of his predecessor Cyamatare and his successor Seemugeshi.

Then comes Gahima with one, perhaps two tales, and before that Mutabaazi about whose reign an unexpected number of ibiteckerezo ( 7 to 10 ) are remembered. But these tales do not form a single whole, but part of two well-defined sets: the popular cycle about the sorcerer

\footnotetext{
"'Se'Se, e.g., the set of tales told by Cinkaniisha to Couper/Kamanzi, Récits or the ser by Mugina in the IRSAC collection and in the dissertation of Nkurikiyimfura.

'"'Coupez/Kamanzi, Récits, full texts; Pagès, Reyaume, summaries; Kalganme Abrégé, only paraphrases ibitcekerczo, often in an incomplete fashion.

'I'For a representative collection of tales about this king sec Pages, Royanme, 228-335. $H c$ is so tamous in Burundi that in one story he becomes a king of Burundi, as in Chretien: "Du hirsute," 10. His name scems to stand for any aggressive Rewandan king who was in parts of Kivu, so that one should not attach any chronological significance to such a mention, contra Newbury, "Trick Cyclists?"
} 
king of Nduga, Mashira, who is also a spirit in the pantheon of Ryangombe, and an earlier sizable set of ibiteekerezo about kings before Mutabaazi. Those dealing with the kings from Bwimba to Mutabaazi are interconnected and complex. No tales are known about kings before Bwimba, until one reaches two sets of tales about origins concerning Gihanga ("the creator" or "the founder") which deal with the origins of kingship and cattle, and the set about the Ibimanuka ("The Fallen from Heaven"), the heavenly origins of the Nyiginya rulers.

Having found this series of sets, we can now say a little more about each of them. For each set we give first the geographical space in which they occur and then point to some of their main features. As we are concerned with the ibiteckerezo as historical sources, we follow a reverse implied chronological order.

\section{[1] From Mazimpaka to Rwabugiri}

The heartland is in Nduga but the tales take us far beyond. From Mazimpaka onwards the set contains a growing number and diversity of ibiteekerezo from reign to reign not only about kings but also about major officials, and even armies. Few tales are complex narratives. Many are straightforward and give fairly concrete details. Some are clumsy as stories but precise as to information. This body of ibiteekerezo contains a great deal of historical interest. A most important finding is that it is only from the reign of Rujugira onwards (well after 1750) that local traditions about land and rights and the succession of local authorities, as well as some information in dynastic poetry, allow crosschecking these ibiteekerezo. Genealogies, even of the great families of the kingdom, become consistent from Rujugira, or perhaps Mazimpaka, onwards, as do traditions about the succession of commanders of the various regiments. The reason given for this has been that the ancestor cult in general-and particularly at courtgoes back only as far as Rujugira. "II4 There also was a local cult at Juru near Kamonyi for the spirit of Mazimpaka. ${ }^{\text {tus }}$ In addition we may point out that the situation conforms to many other cases of oral tradition where people remember the past for the last century or the century and a half before their time.

For this period one can crosscheck court and local sources, which raises the credibility of each source dramatically, even though one caunot claim that they do confirm each other independently. This state of affairs also allows one to obtain a great deal more, and more precise, historical content about the history of government, rights over land, and war. The qualitative difference between this and earlier

"'Melmas, Généalogies, 66. Kagame, "Code ésotérigue," 386.

ins:agès, Royaume, 14()-41, 535. 
periods has long been recognized, even by Kagame, who places this divide, however, already in Yuhi Mazimpaka's reign (early eighteenth century). From that reign onwards he deems it no longer necessary specifically to defend the historical existence of the successive kings he discusses. ${ }^{1116}$ Thus the reconstruction of the whole history of the Nyiginya kingdom falls into two sharply different parts: before and after $c a .1750$. Quite credible reconstructions can be made for the latter part assisted by a wealth of narrative and other data. In contrast ibiteckerezo in the strict sense are the major source available for the earlier part.

\section{[2] Ndoori, Cyaamatare, and Seemugeshi.}

The heartland is in Nduga, but Ndoori is active all over the territory of the present Republic of Rwanda and even beyond in the northwest. The major story line of this tells of the downfall of Cyaamatare and the destruction of his kingdom, followed by Ndoori's struggle to establish a new kingdom, his successes, his tragic death, and the way in which his successor Seemugeshi acquires the dynastic name Mutara, a tale of the greatest importance for the later conception of recurring cycles of kings. A large cloud of separable and popular anecdotes about Ndoori surround this core. They explain curious natural features in the landscape or tell of acts of superhuman valor and miracles of grear cunning. As culture hero, Ndoori is also said to have invented many arts and crafts, especially in the popular mind. He is the legendary king par excellence. In 1907 many believed that he had never died and when a false rumor spread throughout $R$ wanda in 1904 that the German commander in Bujumbura had been inurdered, popular rumor attributed this feat to Ruganzu Ndoori. ${ }^{1177}$ As a legendary king, it is but fitting that Ryangombe, the legendary founder of the kubandwa cult of the Cweezi and assimilated spirits, supposedly "arrived" during his reign and had dealings with him. The main story line in this cycle, though, may contain some historical information, but has not been studied critically.

\section{[3] Mashira}

King of Nduga, not of Rwanda and not a Nyiginya. The action is localized in Nduga and centers on Mashira's powers of prophetic divination in various situations and his magical contests with Mutabaazi. Mashira has also been introduced in the pantheorn of Ryangombe. ${ }^{111}$ Taken at face value, these tales contain very little historical information beyond the claim that the Nyiginya king defeated the king of

"'kKagame, Abrégé, I:134.

"'Czekanowski, Ethnographie, 290.

"mapagès, Royaume, 365, with Kibogo and Mutwa both found in tlac Ndoori cycle as well. 
Nduga, and one should not take them at face value. They obviously belong to a narrative genre of tales of divination and riddles. But why did a body of tales about a foreign king, especially those in which no Nyiginya king even features, become part of the corpus of ibiteckerezo of the Nyiginya kingdom? Such tales may well have been very local traditions which entered the tradition at court, for instance, after the court of Musinga settled in late 1898 near the sacred fig tree called Mashira in Nyanza, a tree at the foot of which Mashira had reputedly been killed. ${ }^{\prime \prime \prime}$ These stories may then have been added to the already well-known tales about the contest between Mutabaazi and Mashira. Or, and this is more likely, they were added to the Nyiginya court tradition during the time when the kingdom really took shape: "in Ndoori's Nduga" as the expression in these tales often has it.

\section{[4] From Bwimba to Mutabaazi.}

The tales are set in the area of Gasaabo to Kigari, Bumbogo, and Rukoma-not in Nduga. These areas are "the hallowed lands" of the later Nyiginya kingdom, for they contain all but two of the important ritual sites of that later kingdom. The tales are of great artistic merit. ${ }^{111}$ Their plots turn around marriages, revenge, and contests between sorcerer-prophets which to Europeans evoke the stuff of medieval romances. Moreover, they are so interconnected that one might even consider them as a single oral novel in which progression is indicated both by the successive careers of the actors, nearly all of whom are kings, and by the widening of the geographic setting from Gasaabo hill to Kigari, Bumbogo, and finally Rukoma. Although former historians of the kingdom have taken them seriously, one is tempted to dismiss the whole set as a cycle of fictional tales built on themes and episodes which are also found in other acknowledged fictional tales (imigani)." But on closer examination, such a dismissal would be rash, for it does not explain certain features of these ibiteckerezo to be discussed later.

[5] Gihanga and the Ibimanuka.

Although these constitute two clearly separate sets containing a small number of tales each, they should be considered together because of their relevance today. As stories of origin they both have been of the greatest importance to Rwandan historical consciousness in this century and are still invoked today to legitimize political action, although they obviously do not contain historical information about the remote past."2 The tales about Gihanga, "the founder," are set in the

1'"Delmas, Géncialogies, 183 and 20 (mana trec in general, for ancestor) and 154 (date).

l'"Smith, Récit, 75-76.

"'Smith, Récit, 15, 79-109.

"'The latest in M. d'Hertefelt and J-P. Chretien,"Mythes et stratégies autour des 
northwest of the Republic of Rwanda in areas that were not part of the kingdom until recent times, although the royal capital contained a shrine for Gihanga. These ibiteekerezo legitimized kingship, as well as some political situations contemporary to their recording after 1900. They also contain many claims to the invention of useful technologies. The tales about the Ibimanuka are located in the northeast of the Republic of Rwanda. and their contents are entirely etiological.

The profile of historical narratives relating to the kingdom of the Nyiginya looks quite familiar. The most frequent profile of traditions, for kingdoms at least, is one of a well-remembered recent past preceded by a void and then traditions about, a culture hero preceded by another void, and then by tales of origin. The latter express notions of cosmology while most-but not all-traditions about culture heroes are etiological, i.e., invented to account for contemporary features that arouse interest. Two oddities about the Nyiginya case are the presence of sets 3 and 4 in the overall sequence and the presence of two sets of tales of origin rather than one ( $5 \mathrm{a}$ and $\mathrm{Sb}$ ), or to put it otherwise, two sets of tales about culture heroes ( 2 and 5 a) rather than one. As to this last feature, there is no major problem with regard to oral tradition: the tales are cosmological and etiological and do not seem to contain any genuine historical memory. A fusion seems to have occurred between what were originally tales of origin in two different political entities. Some clues allow one to speculate that one (Gihanga) was at first associated with the original kingdom of Nduga and the second (Ibimanuka) with the original kingdom of the Nyiginya. The fusion occurred when the two kingdoms were united into the later single kingdom of the Nyiginya, perhaps by Ndoori.

But the insertion of sets 3 and 4 is not so easily explained. The corpus of traditions tells us that there was an early Nyiginya kingdom which preceded the one founded by Ndoori, and that these ibiteckerezo are the remembered traditions about it. That would be strange, for how could it be that so much could be remembered about so early a period and yet nearly nothing at all for the kings following the set of Ndoori? Is it not strange that the tales pertaining to these sets, especially set 4 , are so artistic and sound so much like pure fiction? Take for instance the story about Matama. "13 This begins with

origines du Rwanda" in J.P.Chrétien and J.L. Triand, eds., Histoire d'Afrique: Les Enjeux de la mémoire (Paris, 1999), 281-320. Alreatly by 1958 in an article in Temps Nouveaux (8 June 1958), hasing the Tutsi right co rule on the lhimanuka story. Also M. d'Hertefelt, "Mythes et idéologies dons le Rovanda ancien et contcnuporain" in R.Manny and J. Vansina, eds., The Historian in Troplical Africa (London 1964), 219. 38 .

"Murabaazi $T$ \#1-5, 7, 9 and $H$ \#6-8, 10, 12, 14, 23-24, Cinhindiro, $H$ \#24, for most versions; Coupez/Kamanzi, Récits, 17.3.87. 
the king of Rwanda who magically heard a baby girl Matama cry in a far-off country. The baby Matama cried because its bead had been swallowed by a chicken, which was swallowed by a cat, swallowed by a dog, swallowed by a hyena, swallowed by a lion, swallowed by an elephant. The baby was only pacified when a hunter sent by the king killed the elephant, extracted the lion, then the hyena, then the $\mathrm{dog}$, then the cdt, then the chicken and then the bead. Eventually the king would marry Matama, who would produce the crown prince.

The names of some actors are the only feature that turns the tale into history. The king is Mibambwe Mutabaazi of Rwanda. After he married Matama she gave birth in a known place, the capital Karambo. And apart from this tale Matama is also known to have been buried with her husband at a specific place: Remeera of the Abaforoongo. ${ }^{114}$ So the claim to be historical here lies in the names mentioned, both personal names and toponyms. But how does such a strange combination of fairy tale and "real" names come into being? Is this just fiction in which some actors have been given historical names? That does happen as the romantic tale of the secret love of Bwiza ("Beauty") shows. In some versions the names are vague. But in some she is said to be the daughter of king Mashira of Nduga and her real lover is a son of king Mutabaazi, the one who married Matama, which makes this a tale in Mashira's set. ${ }^{115}$ Given this illustration, one is inclined to attribute the features of nearly all the ibiteckerezo of sets 3 and 4 to such a process.

The tale of Bwiza also gives us a clue as to why a particular royal name should be linked to a particular tale. Mashira becomes her father and Mutabaazi's son her lover, rather than any other kings, because this inserts the whole tale into the larger body of tales about the struggle between those two kings. Hence the attribution of these names (which is not yet complete in all versions!) occurred after a set of tales about the struggle between Mashira and Mutabaazi was already well-known. This does not imply, however, that such a struggle really occurred! After all, the "Mashirá" may just be a nickname, derived from the verb gushira "to finish," and mean "the end [of the Nduga kingdom!]," bestowed by storytellers on the last king of Nduga. "l" As to other royal names bestowed in the tales of set 4 to rulers of kingdoms such as Gisaka, Bugesera, Buha, and Ndorwa, these are all typical, but recent, dynastic names for these kingdoms. They should not be taken literally as they merely signify

\footnotetext{
1"Kagame, Abrégé, 1:81, 85 (and IRSAC collections). The place where Nyanguge gave birth is also known.

"'Mashira, $H \# 4,9$; Mutalanazi, $T$ \#12; Gahindiro, $T \# 10,18$ and $H \# 5$ (filed with the king of the same name); Sinith, Récit, 290-313.

"Note that in Burundi the Abashira, descendants of Mashíra, are "a good Hutu family." F. M. Rodegem, Dictionnaire rundi-français (Tervuren, 1970), 426.
} 
"the ruler of kingdom $X$ ". To account for the names of particular Nyiginya kings in these early tales is far more difficult because there are several possibilities. Rwandans may have felt at one point that a king in a particular fairy tale recalled the stereotyped features of a particular dynastic name in Rwanda or, just as plausibly, that the link between king and tale may be indirect and involve a placename.

For the matter does not end with the attribution of personal names. One still must explain the presence of genuine toponyms in use today, especially place names whose meaning is not intrinsically connected with the tale. ${ }^{17}$ The great majority of toponyms mentioned in set 3 are places that were guarded by hereditary keepers, such as capitals (and possibly the birth place of a named king), sites connected with royal rituals, or royal cemeteries. The link between place name and the supposed historical actor legitimizes the rights and privileges of its guardians. Hence what are now generally known ibiteekerezo stem from what were once their local traditions. The question is whether these traditions derive from memories going all the way back to the creation of the site by the genuine historical actor remembered or not. For instance does the link with Matama, as remembered by the guardians at Karambo, go back to the very time that a genuine actress called Matama really lived there? If so, there was a genuine memory about her which dimmed as time wore on until only her name was remembered. Then the local historians "captured" the fairy story by giving her name to the crying baby and thus provided an arresting tale which raised their own prestige as the guardians of the place.

The same issue applies to other guardians, places and actors : if this was the process in question, then these traditions do retain a memory at least of ancient persons. Or is it the case that a place became special in more recent times, e.g., as the domain of ritualists, or as an administrative capital founded by a later king, or as a burial place for a more recent king whose guardians then gave their place more lustre and raised their own prestige by claiming a foundation at a much earlier time by a famous actor-perhaps already famous because she (usually a queen) or he (usually a king) had already been linked to a fairy story? Again if so, the tradition is utterly misleading, as it masks the genuine history of the foundation of the place. This second possibility is, alas, perhaps more likely than the first as there is much evidence that recently powerful $R$ wandan nobility have lengthened their genealogies to gain prestige, and some royal regiments have claimed to have been created by prestigious kings at a much earlier date than was actually the case. ${ }^{11 x}$ Still one must examine each story

117For example, Nzaratsi in Pagc̀s, Royaumıe, 578, mercly mc:ıns "charms." Nzararsi capital is just "the capiral of charms" in the magit struggle lerween Mutabaazi and Mashira.

"1xThis can be detected by obvious discrepancies in the numbers of ancestors cited or 
separately and consider the history of the guardian group of each locale carefully before a valid opinion can be given as to which of the two processes is likely to have happened.

The most remarkable point about all of this is that if ibiteekerezo in these sets 3 and 4 contain genuine historical information, it consists in the bare mention of names of places and persons. In the Matama story it would be that she lived at Karambo, was a king's mother, and was buried at Remeera. ${ }^{11 y}$ And this situation is exactly what one should have expected. With the passage of time, more and more detailed traditions tend to be forgotten. In the end they are reduced to a personal name or two which are remembered only because they are linked to a place and its guardians. Under such circumstances the urge appears among the guardians to bolster the importance of their site by a nice long story about the person commemorated there. Hence the "capture" of a spectacular fairy story to the nearly forgotten local celebrity. This rather leads to the unexpected conclusion that, since the ibiteckerezo of set 4 especially exhibit the features one could expect from genuinely old information, they are fairly old and might contain a snippet of credible oral tradition! If they had been plausible matter-of fact-tales, as in recent ibiteckerezo, they would be much more suspect! But then we should not forget either that they might still be wilfully anachronistic, so that each case needs to be evaluated on its own merits.

The set about Mashira consists mostly in contests between two seers of prophetic sibylline divination riddles, first set up and then explained as later events unfold, a genre also well known from fiction. It hardly contains any genuine historical information, perhaps only that Nduga was once conquered by a Nyiginya king, perhaps also that Mashira had defeated another population, the Reenge, who once ruled over part of Nduga. It is about the Reenge that Delmas warns us but his words are valid for the whole set of tales about Mashira: "[t]hese legends, which have an historical foundation, have only one fault: they always want to attribute events to places and to bring them back to precise and recent dates." 211

Indeed Rwandans know well that to localize a story in a landscape makes it more believable, a possibility that should be kept in mind when one deals with toponyms, especially those that now refer to places that are otherwise unrenarkable!

gaps in the lists of officeholders remembered. Nearly all non-royal genealogies and lists of regimental officeliolders which go lack beyond Mazimpaka have been lengthened in this scuse.

"She was supposed on be a menilor of the Ha clan and hence the tale has her born in Buha, but perhaps it is the reverse, as she was supposed to be from Buha (a legendary place for farawny brides) she was therefore placed in the Ha clan!

12"Delmas, Généalogies, 40n1. 
Ibiteekerezo constitute the bulk of the available data and form the backbone of the oral history of the Nyiginya kingdom, just as similar tales do in neighboring kingdoms. They can yield much information. Consider for instance what they tell us about Rugaaju (first half of the nineteenth century). ${ }^{121}$ Rugaaju was chosen as a youthful playmate of king Gahindiro. He grew up to be the king's favorite and his lover. In this position he invented a new form of landholding, the political ibikingi, in which an individual received a stretch of land ("hill") and control over its inhabitants as a personal prebend, free from all control by other authorities, a grant which only the king could revoke. Rugaaju accumulated many ibikingi on which he placed his followers and thus became the wealthiest (in land and cattle) man in the kingdom, not even excluding the king.

Despite their relationship, at least one quarrel erupted between Gahindiro and Rugaaju, when the former asserted his authority by killing a close relative of Rugaaju. But the matter was soon resolved amicably. As the political power in the land, Rugaaju was quite arrogant and made many enemies, including a certain Marara. After Gahindiro's death Marara (and no doubt others, including ritualists) convinced the court of Rwogera that Rugaaju had poisoned Gahindiro. He was arrested and killed, along with one of his sons (at least), and his wealth fell in the hands of other chiefs, especially Marara.

But like all other sources ibiteekerezo must be subjected to a critical examination. They cannot be incorporated unchanged as evidence into a history, nor can one arbitrarily erase any "disturbing" features and then directly integrate the rest as evidence. In practice this examimation is achieved to a large extent by a study of variants and the relationship between tales in the whole body of tales. This is why large accessible collections of ibiteekerezo, such as the IRSAC collections, are essential tools in the workshops of historians who study Rwanda.

The quality of ibiteckerezo as sources for history varies considerably from one tale to another. In some cases an untalented storyteller provides a muddled rendering of the tale. In some orhers the luxuriant artistic developments of a tale hide the fact that it contains little ascertainable historical information at all about the period and actors it deals with. Still, as we have seen, even in such cases a careful analysis can sometimes detect "slivers of evidence" embedded in the fiction of such tales. In this regard I am not convinced that a structural analysis of such tales along with an interpretation of symbolic content can recover encrypted historical information. ${ }^{122}$ On the whole (but

\footnotetext{
'2'Sece many items in Scurabyo, Ciahindiro, and Rwogera files; Conpey/Kamanzi, Ricits, 311-17; Kagane, Abrégé I:182-84, 194-96.

1:2As in Luc de Heusch, Rois nés d'un cocur de vache (Paris, 1982).
} 
not always) short stories without much literary development tend to contain more historical information than well-crafted and developed "literary" narratives. The latter often contain a considerable amount of borrowing of purely fictional episodes and motifs of all sorts. Yet even among the more"literary" narratives, many that relate to recent times tend to contain much more credible evidence than most of those that relate to remote times. There does exist a sharp divide within the overall body of tales between those that deal with events supposedly occurring after ca.1750 and those that deal with earlier times. In general, ibiteckerezo concerning the period starting with Rujugira are much more numerous, more reliable, and more easily crosschecked than those that relate to earlier times. The latter tend to be very dificult to interpret reliably, to contain very little information-and information that at present cannot be crosschecked by other means.

In some cases assertions are made in some ibiteekerezo which contradict or contrast those made in others, and allow one to question historical consensus. Thus we have seen that one version of the tale about Mazimpaka's prophecies implies that most of the kings coming between him and Rwaabugiri died young, in contrast to most tales which tell us that two of these kings had long lives and reigns. Or the record about Rwaka cited earlier makes clear that Rujugira seized the throne in a coup, something other accounts are trying to hide.

Furthermore it should be always kept in mind that these ibiteekerezo do not deal with the whole territory of the Republic of Rwanda but only with the Nyiginya kingdom. It is good to know that by ca.1700 this may have covered only about $14 \%$ of the national territory today. ${ }^{123}$ Moreover, the tales focus only on some facets of political history and even that only in context of the royal court, and they mostly consist of anecdotes. Politics apart, they remain silent about the essential domains which are needed to reconstruct an overall meaningful history. Thus they contain no direct information about the history of environmental stresses and contrasts; demography; economics of production, distribution, or consumption; social stratification by status, gender, and age; social or ritual associations; and religious perceptions and practices.

But even so the fact remains that these ibiteekerezo allow one to construct a great deal of the political history of the Nyiginya kingdom from ca.1700 onwards and provide some information about earlier times. They are the main sources informing us about the history of a kingdom which by its end came to dominate a large territory and the lives of perhaps two million people.

12'The earliest tales deal with an area less than $5 \%$ of that of the Rwandan Republic. But by 1700 the population in the Nyiginya kingdom may well have been one-third or so of the population then living in what is now the territory of Rwanda. 


\section{Appendix. A Conventional List of Nyiginya Rulers.}

Ibimanuka Mythical : "The fallen from heaven" ... Set of "non historical" kings.

Gihanga Mythical : "The Founder"

... Set of "non-historical" kings.

RUGANZU (1) Bwimba

CYIRIMA Rugwe

KIGERI Mukobanya

MIBAMBWE Mutabaazi Nyoro invasion. Temporary loss of kingdom

YUHI Gahima Perhaps fictive king (2)

NDAHIRO Cyaamatare

Kingdom collapsed. Anarchy

RUGANZU Ndoori New kingdom

MUTARA Seemugeshi

KIGERI Nyamuheshera Perhaps fictive king (2)

MIBAMBWE Gisanura

YUHI Mazimpaka

[KAREMEERA RWAKA] King later excluded from the list.

Coup

CYIRIMA Rujugira

KIGERI Ndabarasa

MIBAMBWE Sentaabyo (1796-1801)

Coup

YUHI Gahindiro (1801-X)

MUTARA Rwogera

KIGERI Rwabugiri (c, 1865-1895)

MIBAMBWE Rutarindwa(1895-1896)

Coup

YUHI Musinga

(1) Dynastic names are listed in capitals.

(2) No information at all exists about these kings. What is told about them applies in fact to other kings. 